\title{
Genes and structure of selected cytokines involved in pathogenesis of psoriasis
}

\author{
Aldona Pietrzak ${ }^{1}$, Anna Zalewska ${ }^{2}$, Grażyna Chodorowska ${ }^{1}$, Piotr Nockowski ${ }^{3}$, \\ Anna Michalak-Stoma ${ }^{4}$, Pawel Osemlak ${ }^{5}$, Dorota Krasowska ${ }^{1}$ \\ ${ }^{1}$ Department of Dermatology, Medical University of Lublin, Poland \\ ${ }^{2}$ Department of Dermatology, Medical University of Łódź, Poland \\ ${ }^{3}$ Department and Clinic of Dermatology, Venereology and Allergology, Wroclaw Medical University, \\ Poland \\ ${ }^{4}$ Chair of Clinical Immunology, Medical University of Lublin, Poland \\ ${ }^{5}$ Department of Pediatric Surgery and Traumatology, Medical University in Lublin, Poland
}

\begin{abstract}
Psoriasis is a common skin disease involving 1-4\% of human population worldwide, of strong genetic background. The following cytokines are directly involved in psoriasis: TNF, IL-1, IL-2, IL-6, IL-7, IL-8, IL-15, IL-18, IL-19, IL-20, IL-23 whereas IL-4, IL-10, IL-12 as well as IL-11, IL-17 and IFN-gamma are rather indirectly engaged. This work is a review of some genetic factors and structure of selected cytokines and receptors and their genes location.
\end{abstract}

Key words: Skin disease - Psoriasis - Interleukins - Receptors

\section{Introduction}

Psoriasis is a chronic recurrent skin disease of still not fully elucidated etiology, observed in both sexes [1-4]. Literature data point out at strong genetic component, however the mode of inheritance is still unclear and varies in different types of the disease [3]. In $70 \%$ of monozygotic twins, psoriasis develops concomitantly. Probability of psoriasis occurrence reaches for $70 \%$ when both parents are affected in comparison to $1-4 \%$ for the general human population [4-6]. The risk of psoriasis development is higher when the father is affected or is a psoriasis susceptibility gene carrier. This phenomenon is called "genomic imprinting" [5,7].

Some researchers pointed out at autosomal dominant mode of inheritance with $60 \%$ of penetrance $[4,5,8]$, while others multigenic and multifactorial mode of inheritance with environmental factors such as mechanical traumas, dietary factors, infections, psychological stressors, drugs (including lithium, antimalarials, betablockers, NSAiD, salicylates) [4,5,9-14].

Correspondence: A. Zalewska, Dept. of Dermatology, Medical University of Lodz, Krzemieniecka Str. 5, 94-017 Lodz, Poland; tel. (+4842) 6867981, fax.: (+4842) 6884565,

e-mail: zalewska@csk.umed.lodz.pl
Furthermore, significant positive correlation between human leukocyte antigens (HLA) and psoriasis has been observed [15] including class I HLA i.e. HLA-B13, -B17, -B39, -B57, -Cw6 (the most frequently observed), -Cw7 and class II HLA namely DR4, DR7 (the most frequently encountered), -DR55 [4,5,16-19]. HLA-Cw6 positive individuals suffer more frequently from psoriasis than their HLA-Cw6 negative siblings. In 1985, Henseler and Christophers distinguished two types of non-pustular psoriasis namely type I, inheritant and developing before the age of 40, presenting a more severe course than type II, sporadic, developing after the age of 40 with comparatively milder course [20].

It is worth pointing out that in psoriatic patients from different cohorts various linkages and associations have been discovered. This could result from many confounding factors including ascertainment bias, gene-environment interactions, low effect size of individual genetic variation [21].

Up till now, many psoriatic susceptibility loci have been identified including the major ones located on chromosomes 6p, 17q, 4q and 1q, and called PSORS $1,2,3$ and 4, respectively) and the minor ones discovered on chromosomes $16 \mathrm{q}$ and 20p [2,22,23]. Research data identified at least 20 psoriasis suscepti- 
Table 1. Combined data on psoriasis susceptibility loci (with permission from authors Jullien and Barker [24]).

\begin{tabular}{|c|c|c|c|c|}
\hline Locus & Region & Associated gene & Study population & Reference \\
\hline PSORS7 & $1 \mathrm{p}$ & ND & British & [28] \\
\hline \multirow{4}{*}{ PSORS4 } & $1 \mathrm{q}$ & Many within epidermal diffentiation complex & Italian and American & {$[29],[30]$} \\
\hline & $2 p$ & $\mathrm{ND}$ & American and British & {$[28],[29]$} \\
\hline & $2 q$ & ND & British & [31] \\
\hline & $3 p$ & $\mathrm{ND}$ & Swedish & {$[32]$} \\
\hline \multirow{2}{*}{ PSORS5 } & $3 q$ & SLC12A8 & Swedish & {$[32],[33]$} \\
\hline & $4 q 13$ & ND & American and Swedish & {$[29],[32]$} \\
\hline PSORS9 & $4 \mathrm{q} 31$ & $\mathrm{ND}$ & $\begin{array}{l}\text { Chinese, American, } \\
\text { Northen Europe }\end{array}$ & {$[34],[35]$} \\
\hline PSORS3 & $4 q 34$ & IRF-2 & Irish & {$[36],[37]$} \\
\hline \multirow{8}{*}{ PSORS1 } & $6 \mathrm{p} 21.3$ & $\begin{array}{l}\text { HLA-C, HERV-K,HCG27,CDSN,PSORS1C3, } \\
\text { POU5F1,TCF19,CCHCR1,LMP, SEEK1,SPR1 }\end{array}$ & Many & $\begin{array}{l}{[28],[38],[31],[34],} \\
{[35],[32],[39],[40]}\end{array}$ \\
\hline & $6 \mathrm{q}$ & ND & American and German & {$[40]$} \\
\hline & 7 & ND & American & {$[31]$} \\
\hline & $8 \mathrm{q}$ & ND & British & {$[31]$} \\
\hline & $10 \mathrm{q}$ & ND & American and German & {$[40]$} \\
\hline & $14 \mathrm{q}$ & ND & American and British & {$[28],[29]$} \\
\hline & $15 \mathrm{p}$ & ND & Swedish & {$[32]$} \\
\hline & $16 \mathrm{q}$ & & $\begin{array}{l}\text { American, German, } \\
\text { Icelandic }\end{array}$ & {$[40],[41]$} \\
\hline \multirow{4}{*}{ PSORS2 } & $17 \mathrm{q} 25$ & & American and British & $\begin{array}{c}{[42],[32],[33],[40],} \\
{[43]}\end{array}$ \\
\hline & $18 \mathrm{p} 11$ & & Finnish & [44] \\
\hline & $19 \mathrm{p} 13$ & JunB & German and British & {$[45],[39]$} \\
\hline & $20 p$ & ND & $\begin{array}{l}\text { German, British and } \\
\text { American }\end{array}$ & {$[40],[31],[46]$} \\
\hline
\end{tabular}

ND - not determined

bility loci on 15 different chromosomes out of which nine were confirmed by studies in various populations (PSORS 1-9) [24].

Research data on susceptibility locus located on chromosome 6p, called PSORS-1 points out at his locus as the core risk haplotype [25]. Moreover, PSORS1 is the only psoriasis susceptibility locus that has been always identified in genome-wide scans responsible for about $35-50 \%$ of genetic predisposition to psoriasis development [21]. Of note, HLA-Cw6 and nine other genes (CDSN, HCR, POU5F1, TCF 19, HCG 27, PSORS-1C3, SPR1, SEEK1, STG) are located within PSORS-1 region. Furthermore, a highly polymorphic MICA gen was also discovered on chromosome 6, however still beyond PSORS-1 region [26]. It was found that MICA*017 was significantly more frequently observed in patients with psoriasis vulgaris whereas MICA*002 in arthropatic psoriasis [27].

Clinical studies aiming at biologicals involved in psoriasis, including cytokines, their inhibitors, fusion proteins, monoclonal antibodies directed against $\mathrm{T}$ lymphocytes and other leukocytes, employment in psoriasis focused on pathogenic issues on immunological disturbances, which in turn depend on keratinocytes response to inflammatory stimuli. Of importance, psoriatic keratinocytes continuously produce enormously wide spectrum of cytokines showing distinct biological functions (TNF $\alpha$, IL-1, IL-6, IL-7, IL-8，IL-15，IL-18，IL-19，IL-20，IL-23) [71]. The majority of cytokines have pleiotropic effects on different cells and tissues and mutual interactions 
between them are most frequently described as cytokine network.

Generally, cytokines are divided into a Th1-type and Th2-type. Psoriatic plaques demonstrate predominance of Th1-type cytokines such as IL-2 and IFN- $\gamma$ $[72,73]$. However, different research groups revealed other cytokines involvement, which cannot be simply classified as Th1, Th0 or Th2 type, in psoriasis development $[74,75]$.

Furthermore, in psoriasis interactions between different genes have been demonstrated thus leading to various cytokines release which can be regarded as target of future effective therapy.

The updated list of intereleukins involved in psoriasis pathogenesis is presented in Table 2 .

\section{Interleukin-1}

Structure. IL-1 consists of three functionally and structurally related polypeptides: two agonists of IL-1 receptor (IL- $1 \alpha$ and IL-1 $\beta$ ) and one antagonist (IL-1Ra) [76]. IL-1 $\alpha$ and IL-1 $\beta$ are glycoproteins synthesized in a form of precursors with molecular weight of $31 \mathrm{kDa}$ without signal peptide, which are then splitted to mature form of molecular weight of $17 \mathrm{kDa}$. IL- $1 \alpha$ is already active as a precursor, mainly intracelullary. Its mature form can be released from a cell as a result of proIL- $1 \alpha$ to IL- $1 \alpha$ splitting by calcium activated proteases, called calpains. Biological activity of IL-1 $\beta$ results from intracellular cysteine protease ICE splitting (interleukin $1 \beta$-converting enzyme) [76]. Humans have got four forms of IL-1Ra gene product: one soluble isoform (sIL-1Ra) including the signal peptide, with molecular weight of $17 \mathrm{kDa}$, as well as three intracellular isoforms (icIL-1Ra1, icIL-1Ra2 and icIL1Ra3) [77]. sIL-1Ra is secreted by different cells and has different degree of glycosylation, thus different molecular weight ranging from 22 to $25 \mathrm{kDa}$. Intracellular isoforms arise as a result of different cutting and folding of tRNA (icIL-1Ra1) or the alternative place of initiation of gene translation (icIL-1Ra3). sIL-1Ra isoform brakes competitively bonding of IL-1 with receptor on cell surface, however the role of the intracellular isoform remains unknown [77].

Receptor. Family of IL-1 receptors belongs to TLR receptor superfamily (Toll-like receptor). Genes coding IL-1RI, IL-1RII, IL-18R and IL-18RAcP are in cluster of $530 \mathrm{~kb}$ on chromosome $2 \mathrm{q} 12$, gene coding IL $3 \mathrm{q} 28$ $1 \mathrm{RAcP}$ is situated on chromosome $3 \mathrm{q} 28$ [78]. Components of IL-1 receptor family were identified in the last years on the basis of genomic analysis of row newly recognized proteins, in majority with poorly defined function [48]. There are two receptors for IL-1: IL-1RI and IL-1RII [78]. IL-1RI receptor is a protein of $80 \mathrm{kDa}$ molecular weight. It has higher affinity to IL-1 and IL-
Table 2. List of interleukins involved in psoriasis pathogenesis with corresponding genes.

\begin{tabular}{|c|c|}
\hline Interleukin & Chromosome \\
\hline IL-1 family except of IL-18 & $2 \mathrm{q} 13$ [47] \\
\hline IL-18 & $11 \mathrm{q} 22.2-22.3[48]$ \\
\hline IL-2 & $4 q 26-28$ [49] \\
\hline IL-4 & $5 q 23-31[50,51]$ \\
\hline IL-6 & $7 \mathrm{p} 21[52,53,54]$ \\
\hline IL-11 & $19 q 13.3-q 13.4[55,56]$ \\
\hline IL-7 & $8 q 12-q 13$ [57] \\
\hline IL-8 & $4 q 12-4 q 21[58]$ \\
\hline $\mathrm{IL}-10, \mathrm{IL}-19, \mathrm{IL}-20$ and $\mathrm{IL}-24$ & $1 \mathrm{q} 31.3[59,60]$ \\
\hline $\begin{array}{l}\mathrm{IL}-12 \text { p40 } \\
\mathrm{IL}-12 \text { p35 }\end{array}$ & $\begin{array}{l}5 q 31-q 33 \\
3 q 25.33-q 26 \quad[61,62]\end{array}$ \\
\hline IL-23 p19 & $12 \mathrm{q} 13.2$ region $[63]$ \\
\hline IL-15 & $4 q 31[64]$ \\
\hline IL-17 & $2 \mathrm{q} 31$ and $6 \mathrm{p} 12[65,66]$, \\
\hline TNF family & $6 \mathrm{p} 21,3[67.68]$ \\
\hline $\operatorname{IFN} \gamma$ & $12 \mathrm{q} 24.1[69,70]$ \\
\hline
\end{tabular}

1alfa than IL1-RII receptor. It exists on majority of cells sensitive to IL-1, mainly lymphocytes T, fibroblasts, keratinocytes, endothelial cells, hepatocytes. Binding of the third protein namely IL-1RAcP (IL-1 receptor accessory protein), also belonging to IL-1 receptor family, necessary for triggering of cell signal. IL-1RII receptor of $68 \mathrm{kDa}$ molecular weight has higher affinity to IL-1 $\beta$ than to IL- $1 \alpha$, also weak affinity to IL-1Ra. It is mainly found on neutrophiles, monocytes, macrophages, B lymphocytes, bone marrow cells. It exists in a membrane bound and soluble form. Soluble form of IL-1RII also binds with IL-1 $\beta$ precursor, blocking its enzymatic splitting and activation.

\section{Interleukin-2}

Structure. Mature product of gene for IL-2 is a glycoprotein with molecular weight of $15,420 \mathrm{kDa}$ consisting of 133 amino acids [49]. Its structure is composed of four antiparallel amphipathic alfa helices with one intrachain disulfide bond, located between residues 58 and 105 . It is worth pointing out that secondary and tertiary protein structures are required for biologic activity of IL-2 whereas the carbohydrate components are dispensable $[79,80]$.

Receptor. Surface receptor for IL-2 is composed of three kinds of protein chains, which join together non- 
covalently to create different configurations of receptor: chain alpha $(\mathrm{CD} 25$, Tac) with $55 \mathrm{kDa}$ molecular weight, beta (CD122) - 70-75 kDa and chain gamma (CD132, p56) - $64 \mathrm{kDa}$. Receptor consisting of a single chain alpha has the lowest affinity to IL-2, does not transduce signal and is located on some resting $\mathrm{T}$ lymphocytes. Receptor with modest affinity to IL-2 consists of chains beta and gamma, is located on monocytes and the majority of NK cells. Receptor alphabetagamma has the strongest affinity and is located on activated $\mathrm{T}$ and $\mathrm{B}$ lymphocytes as well as on $10 \%$ of NK cells. The number of receptors on activated T lymphocytes is 10 times higher than on activated B lymphocytes. Beta chain plays the most important role in signal transmission to cell interior. Gamma chain is not specific for IL-2R and receptors for IL-4, IL-7, IL-9 and IL-15 also are composed of this chain $[81,82]$. The soluble form of IL-2 receptor (sIL-2R) is formed upon enzymatic cut off of the extracellular part of alpha chain. sIL-2R exerts an immunosuppressive action and competes with IL-2 membrane receptor. sIL-2R is detected in low levels in serum. sIL-2R level increases in some neoplastic and autoimmune diseases, as well as in graft rejection [82-84].

\section{Interleukin-4}

Structure. The molecular weight of this glycoprotein is about $20 \mathrm{kDa}[85,86]$. Its structure is similar to IL-2 and IL-13 and presents a globular nature composed of four short alfa helices [51].

Receptor. IL-4 acts through two types of cell surface receptors - type I and type II. One of these receptor is expressed on a wide range of cells enabling IL-4 to exert its action on various cell types [51]. IL-4 receptor complex is composed of $\alpha$ chain of $120-130 \mathrm{kDa}$ molecular weight (800 amino acids) and $\gamma$ chain CD132/common $\gamma$ chain). The latter is also encountered in receptors for the following cytokines: IL-2, IL-7, IL-9, IL-15 and most probably IL-13 [87-90]. $\gamma$ chain enhances affinity of $\alpha$ chain to IL-4. IL-4R $\alpha$ chain is postulated to be also a component of IL-13 receptor [87,91]. Antibodies of IL-4R $\alpha$ chain inhibit IL-13 binding with its receptor (IL-13R) and thus their function $[91,92]$.

\section{Interleukin-6 and interleukin-11}

Structure. IL-6 and IL-11 belong to a larger cytokine family, sharing a four alpha helix kundle structure, comprising also LIF, CNTF, OSM and CT-1 [93,94]. IL-6 is a glycoprotein of $21-28 \mathrm{kDa}$ molecular weight and consists of 184 amino acids [54]. IL-11 precursor protein consists of 199 amino acids and molecular weight of $23 \mathrm{kDa}$ [56]. Although IL-11 belongs to the same family as IL-6, no similarities are observed in amino acids sequence and in cDNA between these cytokines $[56,95,96]$.

Receptor. IL-6, vIL-6, IL-11, LIF, OSM, CNTF, CT-1 and NNT-1/BSF-3 are also known as gp130 cytokines because they all share gp130 subunit. This subunit serves as a common transducer, by which Janus kinases (Jaks) and transcription factors of the STAT (signal transducers and activators of transcription) family are activated. Moreover, IL-6, IL-11, OSM and CNTF also share IL-11 specific $\alpha$-receptors (IL-11R $\alpha$ ) [97]. IL-11 effects depend on IL-11R $\alpha$ activity, responsible for multimeric signal transduction including gp130 subunit. Two isoforms of the human IL-11R $\alpha$-chain, which differ in their C-terminus domains, have been identified and cloned. One isoform has a cytoplasmic domain and the latter lacks the entire cytoplasmic domain [98].

\section{Interleukin-7}

Structure. IL-7 is a single-chain glycoprotein and consists of six cysteine residues. Both human and mouse proteins contain three disulfide bonds which are essential for the biological activity of this cytokine. The molecular weight of IL-7 is $25 \mathrm{kDa}$ [99].

Receptor. The IL-7 receptor consists of a complex of the IL-7R $\alpha$ chain and the $\gamma c$ chain [100]. Both chains are required for the biological activity of IL-7, which was demonstrated in IL-7R $\alpha$-, $\gamma c-$ and IL-7-deficient mice.

\section{Interleukin-8}

Structure. There are four types of differently processed forms consisting of 69, 72, 77 and 79 amino acids. IL-8 is formed as a precursor protein composed of 99 amino acids. Most frequently it is a monocytederived peptide (72 amino acids). Activated epithelial cells produce a peptide which is 5 amino acids longer [56]. The molecular weight of IL-8 is $8-10 \mathrm{kDa}$ [56].

Receptor. There are two receptors: IL-8 RA and IL-8 $\mathrm{RB}$, expressed on neutrophils, neutrophil-like cells, monocytes, subpopulation of CD8 $+\mathrm{T}$ cells and $\mathrm{CD}$ $56+$ natural killer cells. Additionally, the existence of IL-8 multi-specific receptor (CK) was confirmed and demonstrated on human erythrocytes. CK receptor was demonstrated to be a blood group antigen in the Duffy system [101]. Because of its ability to bind IL-8, this receptor regulates IL-8 level in serum. However, biological effects and stimulation pathways of the CK receptor situated on erythrocytes are still not clearly elucidated. 


\section{Interleukin-10}

Structure. IL-10 belongs to the family of long-chain cytokines, which also encompasses IFN- $\alpha / \beta$ and IFN$\gamma$. Biologically active IL-10 is a homodimer [102] with molecular weight of $37 \mathrm{kDa}$. Each monomer is composed of 160 amino acids with a molecular weight of $18.5 \mathrm{kDa}$. It is of interest that human IL-10 shares $80 \%$ homology with its murine counterpart. Literature data point out at three viral IL-10 homologs namely Epstein-Barr virus (BCRF1) [103,104], herpesvirus type 2 [105], and orf virus [106]. X-ray crystal structure analysis revealed structures of human IL-10 $[107,108]$.

Receptor. IL-10 receptors (IL-10R) are found on normal keratinocytes. They are composed of two different chains: $\alpha$ and $\beta$ (CRFB4) [109], which belongs to class II-cytokine receptor family. The IL-10R $\beta$ chain seems to be essential for IL-10-mediated activity, because characteristic STAT transcription factor activation pattern for IL-10 signaling was observed only in cells expressing both chains [109].

\section{Interleukin-12}

Structure. IL-12 consists of a disulfide heterodimer of $40 \mathrm{kDa}(\mathrm{p} 40)$ and $35 \mathrm{kDa}$ (p35) subunits [110]. The peptide sequences of $\mathrm{p} 35$ and $\mathrm{p} 40$ are similar to IL-6 and the soluble form of its receptor, suggesting that IL12 acts on target cells in a manner similar to the complex of IL-6 and soluble IL-6R [111]. There are also many similarities between Il-12 and Il-23 [111].

Receptor. The functional high-affinity IL-12R comprises IL-12R $\beta 1$ [112] and IL-12R $\beta 2$ subunits [113]. IL-12 p40 binds primarily the IL-12R $\beta 1$ subunit, whereas IL-12 p35 appears to interact mostly with the IL-12R $\beta 2$ chain [113]. Although monometric p40 is secreted in larger quantities than $\mathrm{p} 70$ heterodimer, only the latter is biologically active [114]. This heterodimer is produced after co-expression of both the $\mathrm{p} 40$ and the p35 genes in the same cell [115]. The homodimer binds with a much lower affinity than the heterodimer and therefore acts as an antagonist only at much higher concentrations [116].

\section{Interleukin-15}

Structure. IL-15 is a glycoprotein with molecular weight of $14-15 \mathrm{kDa}$. Its active form consists of 114 amino acids $[117,118]$. It is a member of 4 alpha helix bundle family of cytokines.

Receptor. IL-15 type 1 receptor is found on T lymphocytes and NK cells. It consists of three subunits. Two of them - $\beta$ chain (protein p75) and $\gamma$ chain (protein p64) are components of IL-2 receptor [118, 119]. The third element is a special $\alpha$ chain for IL-15 receptor [120]. The second type of IL-15 receptor is located on mast cells and probably it does not share the same elements with IL-2 receptor. Second type of receptor, which is activated by IL-15 in mast cell proliferation, is characterized by a new subunit initially defined as IL-15RX [121], and now described as an isoform of IL-15R $\alpha$ chain [122].

\section{Interleukin-17}

Interleukin-17 (IL-17) is a first member of a new cytokine family. Of note, up till now it has been discovered only in six species. Whereas, IL-17 is produced mainly by activated CD4+ and CD8+ T lymphocytes, its receptor can be found ubiquitously in the organisms [123].

Structure. Human IL-17 is a protein composed of 155 amino acids and shares about $75 \%$ homology at the nucleotide level and $72 \%$ at the amino acid level with the thirteenth open reading frame of the $\mathrm{T}$ lymphotropic Herpesvirus saimiri (HVS13) [123,124]. IL$17 \mathrm{~A}$ structure sequence does not resemble any other cytokine or mammalian protein [125]. That is why the IL-17 cytokine family seems to represent a distinct ligand-receptor signaling system.

Receptor. As opposed to a relatively restricted expression of IL-17, IL-17 receptor (IL-17R) are ubiquitously expressed in all types of cells and tissues $[65,125,126]$. It appears, that protein structure of IL$17 \mathrm{R}$ is unrelated to those of other cytokine receptor families. The IL-17R chain contains at least seven Nlinked glycosylation sites and the molecular weight of nascent IL-17R protein is approximately $112 \mathrm{kDa}$. IL17R mRNA was detected in epithelial cells, fibroblasts, lymphocytes, myelomonocytic cells and marrow stromal cells [127]. The IL-17R protein as found in peripheral blood $\mathrm{T}$ lymphocytes and vascular endothelial cells [65]. Recent studies have demonstrated other forms of IL-17 receptors, subsequently called IL17RB-E. The above receptors, similarly to IL-17R, are type I transmembrane proteins, but display significant alternative splicing [65].

\section{Interleukin-18}

Structure. IL-18 is produced as a $24-\mathrm{kD}$ inactive precursor lacking a signal peptide (pro-IL-18) [128]. ProIL-18 is cleaved after Asp35 by the endoprotease IL$1 ß$-converting enzyme (ICE; caspase-1) to generate a biologically active, mature $18-\mathrm{kD}$ fragment [128] . IL$1 \beta$ and IL-18 are closely related. Both interleukins have a similar three-dimensional structure [129]. 
Receptor. Interleukin-18 and its receptor, IL-18R, are structurally related to IL-1 and the IL-1R family. All members of the IL-1R family are composed of two chains: the binding chain (IL-1R related protein, IL$18 \mathrm{R} \alpha$ ) and the signaling chain (IL-1R accessory protein-like, IL-18R $\beta$ ) [128-132].

\section{Interleukin-19}

Structure. IL-19 is secreted as monomer. The crystallized monomer has seven helices able to bind to its two-chain receptor [133].

Receptor. Three members of the IL-19 family (IL-19, IL-20 and IL-24) act through the receptor originally defined as the IL-20 receptor [134,135]. Interestingly, IL-20 and IL-24 can also use an alternative receptor and indeed, recent investigations have suggested, that the IL-20 receptor, as originally defined, may be the true IL-19 receptor [136-138]. IL-19 act through the IL-20R( 1 or alfa)/IL-20R(2 or beta) heterodimer which have been involved in triggering abnormal keratinocyte differentiation and proliferation [135]. IL-19 receptor binding results in a rapid activation of the transcription factor STAT3 (signal transducers and activators of transcription 3$)[136,37]$.

\section{Interleukin-20}

Structure. The entire coding sequence translated from full-length IL-20 cDNA clone indicates, that IL-20 is a member of the IL-10 family and it is mostly similar to IL-19 (40\% of sequence identity) [139]. Recombinant human IL-20 produced in BHK (renal cells of new born Syrian hamsters) and baculovirus cells is a monomer [134]. The IL-20 mRNA contains motifs in its 3'untranslated region, that are associated with instability. IL-20 mRNA appears to be rare and short-lived. The polypeptide sequence of IL-20 is similar (20-40\% identical) to that of IL-10 and four other mammalian cytokines [140]. In contrast to IL-10, which only has four conserved cysteine residues in its mature protein sequence, IL-20 contains six of them. However, Gln81 and Asn 134 residues in IL-10, corresponding to Cys81 and Cys134 in IL-20, have a separation of 11.6Ĺ. IL10 , which forms an intercalating dimer contains Asn116 in a potential flexible hinge region between the core of one monomer and the helix contributed by the other monomer [134]. Based on a structural analysis, IL-20 is assumed to share a similar three-dimensional structure [141].

Receptor. Recombinant IL-20 protein stimulates a signal transduction pathway through STAT3 in a keratinocyte cell line, demonstrating a direct action of this ligand. IL-20 receptor is the same as for IL-19 and was identified as a heterodimer of two orphan class II cytokine receptor subunits, which are both expressed in the skin [134]. Binding of the IL-20 ligand depends on a connecting recombinant monomer of IL-20 to IL-20RA/IL-20RB heterodimer complex. The ligand does not bind itself, in any detectable way, with any subunit, which can point that IL-20 does not built homodimer causing impossible ligand-induced homodimerisation of $2 \alpha$ subunits. It is rather unique, that IL-20RA, as well as IL20RB are required for binding the IL-20 ligand. Each of three IL-20 receptor subunits (IL-20RA, IL20RB and IL-22RA) has an individual expression pattern in tissues [142].

\section{Interleukin-23}

Structure. IL-23 is a heterodimer, sharing a p40 subunit with IL-12 [143], but containing a distinct p19 subunit. Thus a human antibody directed against $\mathrm{p} 40$ effectively blocks the action of both IL-12 and IL-23 [143]. Interestingly, IL-12 and IL-23 are both produced by activated (mature) dendritic cells (DCs) and play a key role in promoting differentiation and proliferation of type 1 cytokine-producing naive and memory $\mathrm{T}$ cells, respectively [144].

Receptor. IL-23 binds to IL-12R1, but not to IL$12 \mathrm{R} 2$. This cytokine has a heterodimeric receptor, which uses a novel second subunit, IL-23R, a member of the hematopoietin receptor family [145]. The receptor complex for IL-12/IL-23 is expressed or upregulated on natural killer (NK) and T cells, as well as on cells of the myelomonocytic lineage including DCs. The presence of IL-23R in macrophages and dendritic cells suggests, that IL-23 acts in an autocrine manner [145-148].

\section{Tumor Necrosis Factor}

Structure. The overall structure of TNF is described as a " $\beta$-jellyroll" in which eight antiparallel $\beta$-strands form a sandwich 3D structure. TNF precursor is a 233 amino acid, $26 \mathrm{kDa}$ transmembrane glycoprotein type II, comprising cytoplasmic domain and extracellular C-terminus. As a mature form, TNF is released as an $17 \mathrm{kDa}$ extracellular precursor fragment, consisting of 157 amino acids, as a result of TACE family metalloproteinases activity (TNF-alpha converting enzyme). Biologically active forms, both membrane and soluble ones, are homotrimers consisting of 3 identical protein chains of non-convalescent bindings $[149,150]$.

Receptor. Two TNF cell receptors i.e. TNFRI (also called TNF-R55, TNFR $\beta$, p55, CD120a) of $55 \mathrm{kDa}$ molecular weight and TNFRII (TNF-R75, TNFR $\alpha$, 
p75, CD120b) of $75 \mathrm{kDa}$ molecular weight can be demonstrated. There are transmembrane glycoproteins of different degree of glycosylation, molecular weight, affinity and type of signal transduction. TNFRI seems to be responsible for the majority of TNF activity. However, TNFRII exerts a stronger affinity to transmembrane pro-TNF $[149,151]$. TNFRI and TNFRII are present on all cell types except for erythrocytes. TNFRI expression is constitutive in most cell types, whereas expression of TNFRII appears to be inducible [150]. Soluble forms of both TNF receptors -TNFRI and TNFRII are encountered in the blood. The above forms are formed through proteolysis of extracellular fragment, like the mature TNF. By binding TNF, soluble receptors exert an inhibitory or modulatory effect on TNF itself. On the other hand, however, they block dissociation of the active homotrimer to biologically inactive monomers thus prolonging TNF activity $[149,152]$. Both receptors, apart from TNF, bind to LT- and one of LT- $\beta$ (LT- $\alpha 2 \beta 1$ ). TNF receptors are discovered on all nuclear mammal cells and their number does not correlate with response to TNF. IL-1, IL2, IFN- $\gamma$ and TNF itself enhance the expression of TNF receptors. Stimulation of TNF receptors leads to protein kinases $\mathrm{A}$ and $\mathrm{C}$ activation together with NF-AT, NF-kB and AP-1 transcription factors $[151,153,154]$.

\section{Interferon- $\gamma$}

Interferons form a separate groups of proteins produced by numerous cells as a result of viral infection or antigen stimulation $[56,155]$.

Structure. IFN- $\gamma$ is the only type II interferon, classified to this group because of its unique amino acid sequence. IFN- $\gamma$ in its biologically active form is a $34 \mathrm{kDa}$ homodimer stabilized by non-covalent forces. The peptide is heterogenous in size and charge, due to enzymatic trimming of the $\mathrm{C}$-terminus and to variation in degree of glycosylation. This heterogeneity seems to be unimportant for biological activity on cells but might well influence the dynamics of tissue distribution $[1,156]$.

Receptor. Receptors for IFN- $\gamma$ are located on the surface of most of the cells of the body, so that many organs and systems are sensitive to IFN- $\gamma$ action. Expression of IFN- $\gamma$ receptor differ from cell to cell. The highest expression of receptors is observed on Tand B-lymphocytes, NK cells, monocytes, macrophages, fibroblasts, neutrophils, endothelial and smooth muscle cells. The receptor for IFN- $\gamma$ is composed of two structurally homologous polypeptides IFN- $\gamma$ - Ra and IFN- $\gamma-\mathrm{Rb}$. The signal transduction is mediated by Jak1, Jak2 and STAT1a $[156,157]$.

\section{Conclusions and summing-up}

Since mid of the twenties century, dynamic development on cytokine knowledge allowed not only to elucidate mechanism of traditional anti-psoriatic treatments but create the basis for elaboration of new effective biologicals. Fairly recently first cytokine antagonists were registered for the treatment of autoimmunological inflammatory diseases, including skin and arthropatic psoriasis, demonstrating much higher efficacy than traditional therapies $[150,155,158-160]$.

When thinking about biologicals employment, detailed knowledge on genes and receptors of cytokines and their structure is of importance for psoriasis. Data on this subject allow to understand treatment f8ilures observed during many anti-cytokine therapies as for example when anti-IL-8 is used. Despite many theoretical aspects pointing out at antiIL-8 as a very effective anti-psoriatic component, this anti-cytokine effects observed in practice were totally disappointing. This lack of efficacy could at least be partly explained by the presence of additional IL-8 receptors on erythrocytes. On the other hand, further, still not fully elucidated, interactions of cytokine network could be to blame. This is why a single cytokine introduction to anti-psoriatic treatment could at first lead to clinical improvement, expressed as decrease in PASI score (Psoriasis Area and Severity Index). However later usually a quick relapse of psoriasis follows.

Literature data report both most spectacular successes and disappointments of anti-cytokine treatments in selected diseases, as for example in septic shock [76]. Specially, the latter suggest the necessity of more advanced therapeutic strategies implementation taking into account considerable diversity of signal transduction and mutual interactions between different cytokines and their receptors. It is of importance that cytokine expression alters with the disease progression. However, up till now, only single cytokines at a time are used in therapy. There are no schemes of combined anti-cytokine treatment taking into account multi-cytokine approach. Multi-drug schemes of different anti-cytokine treatment, administered at different stages of the disease should be elaborated in the near future.

Acknowledgements: The authors would like to express their great thanks to Professor Jacek Rolinski for critical revision of the manuscript.

\section{References}

[ 1] Chodorowska G. Plasma concentrations of IFN- $\gamma$ and TNF- $\alpha$ in psoriatic patients before and after local treatment with dithranol ointment. J Eur Acad Dermatol Venereol. 1998;10: 147-151.

[2] Janowski K. Personality components of doping with stress in psoriatic patients (Polish). Lublin:Polihymnia, 2006. 
[3] Nickoloff BJ, Nestle FO. Recent insights into the immunopathogenesis of psoriasis provide new therapeutic opportunities. J Clin Invest. 2004;113:1664-1675.

[ 4] Swanbeck G, Inerot A, Martinsson T, Wahlström J. A population genetic study of psoriasis. Br J Dermatol. 1994;131:3239 .

[ 5] Elder JT, Nair RP, Voorhees JJ. Epidemiology and the genetics of psoriasis. J Invest Dermatol. 1994;102:24S-27S.

[6] Gudjonsson JE, Johnston A, Sigmundsdottir H, Valdimarsson H. Immunopathogenic mechanisms in psoriasis. Clin Exp Immunol. 2004;135:1-8.

[ 7] Burden AD, Javed S, Bailey M, Hodgins M, Connor M, Tillman D. Genetics of psoriasis: paternal inheritance and a locus on chromosome 6p. J Invest Dermatol. 1998;110:958-960.

[ 8] Brandrup F, Holm N, Grunnet N, Hennigsen K, Hansen HE. Psoriasis in monozygotic twins: variations in expression in individuals with identical genetic constitution. Acta Derm Venereol. 1982;62:229-236.

[9] Suarez-Almazor ME, Russell AS. The genetics of psoriasis. Haplotype sharing in siblings with the disease. Arch Dermatol. 1990;126:1040-1042.

[10] Toruniowa B, Kądziela-Wypyska G, Urban J. Clinical course of psoriasis In children hospitalized at the Departament of Dermatology, Medical Academy In Lublin between 19801990. (Polish) Przegl Dermatol 1992;79:273-278.

[11] Grossman RM, Krueger J, Yourish D, et al. Interleukin 6 is expressed in high levels in psoriatic skin and stimulates proliferation of cultured human keratinocytes. Proc Natl Acad Sci USA. 1989;86:6367-6371.

[12] Krueger GG, Duvic M. Epidemiology of psoriasis: clinical issues. J Invest Dermatol. 1994;102,14S-18S.

[13] Naldi L, Parazzini F, Peli L, Chatenoud L, Cainelli T. Dietary factors and the risk of psoriasis. Result of an Italian case control study. Br J Dermatol. 1996;134:101-106.

[14] Gelfand JM, Neimann AL, Shin DB, Wang X, Margolis DJ, Troxel AB. Risk of myocardial infarction in patients with psoriasis. JAMA. 2006;296:1735-1741.

[15] Saneczko F, Kaszuba A, Trznadel-Budźko E. Human leukocyte antigens (HLA) in psoriasis. (Polish) Pol Merk Lek. 1997;3:210-212.

[16] Allen MH, Veal C, Faassen A, et al. A non - HLA gene within the MHC in psorisis. Lancet. 1999;353:1589-1590.

[17] Ahnini RT, Camp NJ, Cork MJ, et al. Novel genetic association between the corneodesmosin (MHC S) gene and susceptibility to psoriasis. Hum Mol Genet. 1999;8:1135-1140.

[18] Enerbäck C, Martinsson T, Inerot A, et al. Significantly earlier age at onset for the HLA-Cw6-positive than for the Cw6-negative psoriatic sibling. J Invest Dermatol. 1997;109:695-696.

[19] Kaszuba A, Saneczko F, Trznadel-Budźko E. Psoriasis and genom. (Polish). Post Dermatol. 1998;15:217-223.

[20] Henseler T, Christophers E. Psoriasis of early and late onset: characterization of two types of psoriasis vulgaris. $\mathrm{J} \mathrm{Am} \mathrm{Acad}$ Dermatol. 1985;13:450-456

[21] Liu Y, Krueger JG, Bowcock AM. Psoriasis: genetic associations and immune system changes. Genes and Immunity. 2007;8:1-12

[22] Kirby B, Griffiths CEM. Psoriasis: the future. Br J Dermatol. 2001;144;suppl. 58:37-43

[23] Hensler T. Genetics of psoriasis. Arch Dermatol Res. 1998; 290:463-476.

[24] Jullien D, Barker JN. Genetics of psoriasis. J Eur Acad Dermatol Venereol. 2006;20;suppl. 2:42-51.

[25] Elder JT, Cluster 17 Collaboration. Fine mapping of the psoriasis susceptibility gene PSORS1: a reassessment of risk associated with a putative risk haplotype lacking HLA-Cw6. J Invest Dermatol. 2005;124:921-930.

[26] Korendowych E, Ravindran J, Owen PA, Carmichael CR, McHugh NJ, Dawkins RL. Disease-specific alleles of the
MHC class I related gene, MICA, are associated with type I psoriasis and psoriatic arthritis. Br J Dermatol. 2006;154: 154.

[27] Szczerkowska-Dobosz A. Report from the IVth Psoriasis Congress from gene to clinic. London, 1-3.12.2005. (Polish) Post Dermatol Alergol. 2006;23:42-44.

[28] Veal CD, Clough RL, Barber RC, et al. Identification of a novel psoriasis susceptibility locus at $1 \mathrm{p}$ and evidence of epistasis between PSORS1 and candidate loci. J Med Genet 2001;38:7-13.

[29] Bhalerao J, Bowcock AM. The genetics of psoriasis: a complex disorder of the skin and immune system. Hum Mol Genet. 1998;7:1537-1545.

[30] Capon F, Novelli G, Semprini S, et al. Searching for psoriasis susceptibility genes in Italy: genome scan and evidence for a new locus on chromosome 1. J Invest Dermatol. 1999;112: 32-35.

[31] Trembath RC, Clough RL, Rosbotham JL, et al. Identification of a major susceptibility locus on chromosome $6 \mathrm{p}$ and evidence for futher disease loci revealed by a two stage genomewide search in psoriasis. Hum Mol Genet. 1997;6:813-820.

[32] Samuelsson L, Enlund F, Torinsson A, et al. A genome-wide search for genes predisposing to familial psoriasis by using a stratification approach. Hum Genet. 1999;105:523-529.

[33] Enlund F, Samuelsson L, Enerback C, et al. Psoriasis susceptibility locus in chromosome region $3 \mathrm{q} 21$ identified in patients from southwest Sweden. Eur J Hum Genet. 1999;7: 783-790.

[34] Zhang XJ, He PP, Wang ZX, et al. Evidence for a major psoriasis susceptibility locus at $6 \mathrm{p} 21$ (PSORS1) and a novel candidate region at $4 \mathrm{q} 31$ by genome-wide scan in Chinese Hans. J Invest Dermatol. 2002;119:1361-1366.

[35] Sagoo GS, Tazi-Ahnini R, Barker JW, et al. Meta-analysis of genome-wide studies of psoriasis susceptibility reveals linkage to chromosomes $6 \mathrm{p} 21$ and $4 \mathrm{q} 28-\mathrm{q} 31$ in Caucasian and Chinese Hans population. J Invest Dermatol. 2004;122:14011405.

[36] Matthews D, Fry L, Powles A, et al. Evidence that a locus for familial psoriasis maps to chromosome 4q. Nat Genet. 1996; 14:231-233.

[37] Foerster J, Nolte I, Junge J, et al. Haplotype sharing analysis identifies a retroviral dUTPase as a candidate susceptibility gene for psoriasis. $J$ Invest Dermatol. 2005;124:99-102.

[38] Foerster J, Nolte I, Schweiger S, et al. Evaluation of the IRF2 gene as a candidate for PSORS3. J Invest Dermatol. 2004;122:61-64.

[39] Lee YA, Ruschendorf F, Windemuth C, et al. Genomewide scan in German families reveals evidence for a novel psoriasis -susceptibility locus on chromosome 19p13. Am J Hum Genet. 2000;67:1020-1024.

[40] Nair RP, Henseler T, Jenisch S, et al. Evidence for two psoriasis susceptibility loci (HLA and 17q) and two novel candidate regions (16q and $20 \mathrm{p}$ ) by genome-wide scan. Hum Mol Genet. 1997;6:1349-1356.

[41] Karason A, Gudjonsson JE, Upmanyu R, et al. A susceptibility gene for psoriatic arthritis maps to chromosome 16 q: evidence for imprinting. Am J Hum Genet. 2003;72:125131.

[42] Tomfohrde J, Silverman A, Barnes R, et al. Gene for familial psoriasis susceptibility mapped to the distal end of human chromosome 17q. Science. 1994;264:1141-1145.

[43] Zheng J, Jin S, Shi R. Confirmation of PSORS psoriasis susceptibility loci in a Chinese population. Arch Dermatol Res. 2003;295:14-18.

[44] Asumalahti K, Laitinen T, Lahermo P, et al. Psoriasis susceptibility locus on 18 revealed by genome scan in Finnish families not associated with PSORS1. J Invest Dermatol. 2003; 121:735-740 
[45] Zenz R, Eferl R, Kenner L, et al. Psoriasis-like skin disease and arthritis caused by inducible epidermal deletion of Jun proteins. Nature. 2005;437:369-375.

[46] Nair RP, Stuart P, Henseler T, et al. Localization of psoriasissusceptibility locus PSORS1 to a $60-\mathrm{kb}$ interval telomeric to HLA-C. Am J Hum Genet. 2000;66:1833-1844.

[47] Nicklin MJH, Barton JL, Nguyen M, FitzGerald MG, Duff GW, Kornman K. A sequence-based map of the nine genes of the human interleukin-1 cluster. Genomics. 2002;79:718 725.

[48] Sims JE. IL-1 and IL-18 receptors, and their extended family. Curr Opin Immunol. 2002;14:117-122.

[49] 49.Fletcher M, Goldstein AL. Recent advances in the understanding of the biochemistry and clinical pharmacology of interleukin-2. Lymphokine Res. 1987;6:45-57.

[50] Frazer KA, Ueda Y, Zhu Y, et al. Computional and biological analysis of $680 \mathrm{~kb}$ of DNA sequence from the human $5 \mathrm{q} 31$ cytokine gene cluster region. Genome Res. 1997;7:495-512.

[51] Keegan AD. IL-4. In: Oppenheim JJ et al., Eds. Cytokine reference. T.1, San Diego: Academic Press, 2000;127.

[52] Kishimoto T. The biology of interleukin-6. Blood. 1989; $74: 1-10$.

[53] Le J, Vilček J. Interleukin-6: a multifunctional cytokine regulating immune reactions and the acute phase protein response. Lab Invest. 1989;61:588-602.

[54] Szepietowski JC, Bielicka E, Nockowski P, Noworolska A, Wasik F. Increased interleukin-7 levels in the sera of psoriatic patients: Lack of correlations with interleukin-6 levels and disease intensity Clin Exp Dermatol. 2000;25:643-647.

[55] Mc Kinley D, Wu Q, Yang-Feng T, Yang YC. Genomic sequence and chromosomal location of human interleukin-11 gene (IL-11). Genomics. 1992;13:814-819.

[56] Robak T. Biologia i farmakologia cytokin. Warszawa: Wydawnictwo Naukowe PWN, 1995.

[57] Sutherland GR, Baker E, Fernandez KE, et al. The gene for human interleukin 7 (IL7) is at 8q12-13. Hum Genet. 1989; 82:371-372

[58] Iizasa H, Matsushima K. IL-8. In: Oppenheim JJ et al., Eds. Cytokine reference. T.1, San Diego: Academic Press, 2000;1061-1067.

[59] Gallagher G, Dickensheets H, Eskdale J, et al. Cloning, expression and initial characterization of interleukin-19 (IL19), a novel homologue of human interleukin-10 (IL-10) Genes Immun. 2000;1:442-450.

[60] Fickenscher H, Hor S, Kupers H, Knappe A, Wittmann S, Sticht H. The interleukin-10 family of cytokines. Trends Immunol. 2002;23:89-96.

[61] Sieburth D, Jabs EW, Warrington JA, et al. Assignment of genes encoding a unique cytokine (IL-12) composed of two unrelated subunits to chromosomes 3 and 5. Genomics. 1992; 14:59-62.

[62] Litjens NH, van der Plas MJ, Ravensbergen B, et al. Psoriasis is not associated with IL-12p70/IL-12p40 production and IL12B promoter polymorphism. J Invest Dermatol. 2004;122: 923-926.

[63] NCBI Entrez Gene. IL23A interleukin 23, alpha subunit p19 [online]. [18.04.2007]. <http://www.ncbi.nlm.nih.gov/ entrez/query.fcgi?db=gene\&cmd=Retrieve\&dopt=full_report \&list uids $=51561>$

[64] Krause H, Jandrig B, Wernicke C, Bulfone-Paus S, Pohl T, Diamantstein T. Genomic structure and chromosomal localization of the human interleukin 15 gene (IL-15). Cytokine. 1996;8:667-674.

[65] Moseley TA, Haudenschild DR, Rose L, Reddi AH. Interleukin-17 family and IL-17 receptors. Cytokine Growth Factor Rev. 2003;14:155-174.

[66] Kolls JK, Linden A. Interleukin-17 family members and inflammation. Immunity. 2004;21:467-476.
[67] Goetz FW, Planas JV, MacKenzie S. Tumor necrosis factor. Dev Comp Immunol. 2004;28:487-495.

[68] Makhatadze NJ. Tumor Necrosis Factor Locus: Genetic Organisation and Biological Implications. Human Immunol. 1998;59:571-579.

[69] Trent JM, Olson S, Lawn RM. Chromosomal localization of human leukocyte, fibroblast, and immune interferon genes by means in situ hybridization. Proc Natl Acad Sci USA. 1982;79:7809-7813.

[70] Bureau JF, Bihl F, Brahic M, Paslier DL. The gene coding for interferon- $\gamma$ is linked to the D12S335 and D12S313 microsatellites and to the MDM2 gene. Genomics. 1995;28: 109-112.

[71] Wojas-Pelc A, Ciszek M, Kurnyta M, Marcinkiewicz J. Cytokine network in psoriasis. Cross-talk between keratinocytes and cells of the skin immune system. Centr Eur $J$ Immunol. 2006;31:111-116.

[72] Uyemura K, Yamamura M, Fivenson DF, Modlin RL, Nickoloff BJ. The cytokine network in lesional and lesionfree psoriatic skin is characterized by a T-helper type 1 cell-mediated response. J Invest Dermatol. 1993;101:701705.

[73] Schlaak JF, Buslau M, Jochum W, et al. T cells involved in psoriasis vulgaris belong to the Th1 subset.J Invest Dermatol. 1994;102:145-149.

[74] Barna M, Snijdewint FGM, Van der Heijden FL, Bos JD, Kapsenberg ML. Characterization of lesional psoriatic skin T lymphocyte clones. Acta Derm Venereol Suppl (Stockh). 1994;186:9-11.

[75] Vollmer S, Menssen A, Trommler P, Schendel D, Prinz JC. T lymphocytes derived from skin lesions of patients with psoriasis vulgaris express a novel cytokine pattern that is distinct from that of T helper type 1 and T helper type 2 cells. Eur $J$ Immunol. 1994;24:2377-2382.

[76] Dinarello CA. Biologic basis for interleukin-1 in disease. Blood. 1996;87:2095-2147.

[77] Arend WP, Guthridge CJ. Biological role of interleukin 1 receptor antagonist isoforms. Ann Rheum Dis. 2000;59;suppl. 1:i60-i64.

[78] Subramaniam S, Stansberg C, Cunningham C. The interleukin 1 receptor family. Dev Comp Immunol. 2004;28:415-428.

[79] Robb RJ, Smith KA. Heterogenecity of human T-cell growth factor(s) due to variable glycosylation. Mol Immunol. 1981; 18:1087-1094

[80] Smith KA. IL-2. In: Oppenheim JJ et al., Eds. Cytokine reference. T.1, San Diego:Academic Press, 2000;113.

[81] Minami Y, Kono T, Miyazaki T, Taniguchi T. The IL-2 receptor complex: its structure, function, and target genes. Annu Rev Immunol. 1993;11:245-267.

[82] Gołab J, Jakóbisiak M, Lasek W. Immunologia. Warszawa: Wydawnictwo Naukowe PWN, 2006.

[83] Kemmett D, Symons JA, Colver GB, Duff GW. Serum-soluble interleukin 2 receptor in psoriasis. Failure to reflect clinical improvement. Acta Derm Venereol. 1990;70:264267.

[84] Takematsu H, Tagami H. Interleukin 2 soluble interleukin 2 receptor, and interferon- in the suction blister fluids from psoriatic skin. Arch Dermatol Res. 1990;282:149-152.

[85] Powers R, Garrett DS, March CJ, Frieden EA, Grőnenborn AM, Clore GM. Three-dimentional solution structure of human IL-4 by multidimensional heteronuclear magnetic resonance spectroscopy. Science. 1992;256:1673-1677.

[86] Wlodawer A, Pavlovsky A, Gustchina A. Crystal structure of human recombinant IL-4 at 2,25 A resolution. FEBS Lett. 1992;309:59-64

[87] de Vries JE, Punnonen J. Interleukin-4 and Interleukin-13. In: Snapper CM, Ed. Cytokine regulation of humoral immunitybasic and clinical aspects, Chichester: John Wiley \& Sons, 1996;195-215. 
[88] Idzerda RL, March CJ, Mosley B, et al. Human interleukin 4 receptor confers biological responsiveness and defines a novel receptor superfamily. J Exp Med. 1990;171:861873.

[89] Kondo M, Takeshita T, Ishii N, et al. Sharing of the interleukin-2 (IL-2) receptor chain between receptors for IL-2 and IL-4. Science. 1993;262:1874-1877.

[90] Noguchi M, Nakamura Y, Russell SM, et al. Interleukin-2 receptor chain: a functional component of theinterleukin-7 receptor. Science. 1993;262:1877-1880.

[91] Zurawski SM, Chomarat P, Djossou O, et al. The primary binding subunit of the human interleukin-4 receptor is also a component of the interleukin-13 receptor. J Biol Chem. 1995; 270:13869-13878.

[92] Roliński J. Importance of cytoines and their receptors. In: Lymphocytes apoptosis In patients with chronic B-cell leukemia: habilitation thesis. Lublin, Akademia Medyczna 1998.

[93] Bazan J. Haematopoietic receptors and helical cytokines. Immunol Today. 1990;11:350-354.

[94] Hirano T, Fukada T. IL-6 ligand and receptor family. In: Oppenheim JJ et al., Eds. Cytokine reference. T.1, San Diego: Academic Press, 2000;521-563.

[95] Du XX, Wiliams DA. Interleukin-11: review of molecular, cell biology, and clinical use. Blood. 1997;89:3897-3908.

[96] Du XX, Williams DA. Interleukin-11: a multifuncional growth factor derived from the hematopeietic microenvironment. Blood. 1994;83:2023-2030.

[97] Keith JC , Albert A, Sonis ST, Pfeiffer CJ, Schaub RG. IL11 a pleiotropic cytokine: exciting new effects of IL-11 on gastrointestinal mucosal biology. Stem Cells. 1994;12;suppl. 1: 79-90.

[98] Keith CK Jr. IL 11. In: Oppenheim JJ et al., Eds. Cytokine reference. T.1, San Diego: Academic Press, 2000;565-584.

[99] Spitz H. IL-7. In: Oppenheim JJ et al., Eds. Cytokine reference. T.1, San Diego: Academic Press, 2000;137-153.

[100] Noguchi M, Nakamura Y, Russell SM, et al. Interleukin-2 receptor gamma chain: a functional component of the interleukin-7 receptor. Science. 1993;262:1877-1880.

[101] Horuk R. The interleukin-8 receptor family: from chemokines to malaria. Immunol Today. 1994;15:169-174.

[102] de Waal Malefyt R. IL-10. In: Oppenheim JJ et al., Eds. Cytokine reference. T.1, San Diego: Academic Press, 2000;165-185.

[103] Hsu DH, De Waal Malefyt R, Fiorentino DF, et al. Expression of interleukin-10 activity by Epstein-Barr virus protein BCRF1. Science. 1990;250:830-832.

[104] Zdanov A, Schalk-Hihi C, Menon S, Moore KW, Wlodawer A. Crystal structure of Epstein-Barr virus protein BCRF1, a homolog of cellular interleukin-10. J Mol Biol. 1997;268: 460-467.

[105] Rode HJ, Bugert JJ, Handermann M, et al. Molecular characterization and determination of the coding capacity of the genome of equine herpesvirus type 2 between the genome coordinates 0.235 and 0.258 (the EcoRI DNA fragment N;4.2kbp). Virus Genes. 1994;9:61-75.

[106] Fleming SB, McCaughan CA, Andrews AE, Nash AD, Mercer AA. A homolog of interleukin-10 is encoded by the poxvirus orf virus. $J$ Virol. 1997;71:4857-4861.

[107] Zdanov A, Schalk-Hihi C, Gustchina A, Tsang M, Weatherbee J, Wlodawer A. Crystal structure of interleukin-10 reveals the functional dimer with an unexpected topological similarity to interferon gamma. Structure. 1995;3:591-601.

[108] Asadullah K, Sabat R, Wiese A, Döcke·WD, Volk HD, Sterry W. Interleukin-10 in cutaneous disorders: implications for its pathophysiological importance and therapeutic use. Arch Dermatol Res. 1999;291:628-636.
[109] Asadullah K, Sabat R, Friedrich M, Volk HD, Sterry W. Interleukin-10: an important immunoregulatory cytokine with major impact on psoriasis. Curr Drug Targets Inflamm Allergy. 2004;3:185-192.

[110] Kobayashi M, Fitz L, Ryan M, et al. Identification and purification of natural killer cell stimulatory factor (NKSF), a cytokine with multiple biologic effects on human lymphocytes. J Exp Med. 1989;170:827-845.

[111] Barrie AM, Plevy SE. The interleukin-12 family of cytokines: Therapeutic targets for inflammatory disease mediation. Clin Appl Immunol Rev. 2005;5:225-240.

[112] Chua AO, Chizzonite R, Desai BB, et al. Expression cloning of a human IL-12 receptor component: a new member of the cytokine receptor superfamily with strong homology to gp130. J Immunol. 1994;152:128-136.

[113] Presky DH, Yang H, Minetti LJ, et al. A functional interleukin 12 receptor complex is composed of two beta-type cytokine receptor subunits. Proc Natl Acad Sci USA. 1996; 93:14002-14007.

[114] D'Andrea A, Rengaraju M, Valiante NM, et al. Production of natural killer cell stimulatory factor (interleukin-12) by peripheral blood mononuclear cells. $J$ Exp Med. 1992;176: 1387-1398.

[115] Shaker OG, Moustafa W, Essmat S, Abdel-Halim M, ElKomy M. The role of interleukin-12 in the pathogenesis of psoriasis. Clin Biochem. 2006;39:119-125.

[116] Ling P, Gately MK, Gubler U, et al. Human IL-12 p40 homodimer binds to the IL-12 receptor but does not mediate biologic activity. J Immunol. 1995;154:116-127.

[117] Waldmann T, Tagaya Y. The multifaceted regulation of interleukin-15 expression and the role of this cytokine in NK cell differentiation and host response to intracellular pathogens. Annu Rev Immunol. 1999;17:19-49.

[118] Waldmann TA, Tagaya Y. Interleukin-15. In: Oppenheim JJ et al., Eds. Cytokine reference. T.1, San Diego: Academic Press, 2000;213-223.

[119] Giri JG, Ahdieh M, Eisenman J, et al. Utilization of the $\beta$ and $\gamma$ chains of the IL-2 receptor by the novel cytokine IL15. EMBO J. 1994;13:2822-2830.

[120] Giri JG, Kumaki S, Ahdieh M, et al. Identification and cloning of a novel IL-15 binding protein that is structurally related to the $\alpha$ chain of the IL-2 receptor. EMBO J. 1995; 14:3654-3663.

[121] Tagaya Y, Burton JD, Miyamoto Y, Waldmann TA. Identification of a novel receptor/signal transduction pathway for IL-15/T in mast cells. EMBO J. 1996;15:4928-4939.

[122] Budagian V, Bulanova E, Orinska Z, et al. A promiscuous liaison between IL-15 receptor and Axl receptor tyrosine kinase in cell death control. EMBO J. 2005;24:4260-4270.

[123] Witowski J, Książek K, Jörres A. Interleukin-17: a mediator of inflammatory responses. Cell Mol Life Sci. 2004;61:567579 .

[124] Teunissen MBM, Koomen CW, de Waal Malefyt R, Wierenga EA, Bos JD. Interleukin-17 and interferon- $\gamma$ synergize in the enhancement of proinflammatory cytokine production by human keratinocytes. $J$ Invest Dermatol. 1998;111:645649.

[125] Yao Z, Painter SL, Fanslow WC, et al. Human IL-17: a novel cytokine derived from T cells. J Immunol. 1995;155:54835486.

[126] Dumont FJ. IL-17 cytokine/receptor families: emerging targets for the modulation of inflammatory responses. Expert Opin Ther Patents. 2003;13:287-303.

[127] Silva WA, Jr., Covas DT, Panepucci RA, et al. The profile of gene expression of human marrow mesenchymal stem cells. Stem Cells. 2003;21:661-669.

[128] Gracie JA, Robertson SE, McInnes IB. Interleukin-18. J Leukoc Biol. 2003;73:213-224 
[129] Dinarello CA. Interleukin 1 and interleukin 18 as mediators of inflammation and the aging process. Am J Clin Nutri. 2006;83:447S-455S.

[130] Okamura H, Tsutsui H, Kashiwamura S, Yoshimoto T, Nakanishi K. IL-18. In: Oppenheim JJ et al., Eds. Cytokine reference. T.1, San Diego:Academic Press, 2000; 337-350

[131] Torigoe K, Ushio S, Okura T, et al. Purification and Characterization of the Human Interleukin-18 Receptor. J Biol Chem. 1997;272:25737-25742.

[132] Nakanishi K, Yoshimoto T, Tsutsui H, Okamura H. Interleukin-18 regulates both Th1 and Th2 responses. Annu Rev Immunol. 2001;19:423-474.

[133] Gallagher G, Eskdale J, Jordan W, et al. Human interleukin19 and its receptor: a potential role in the induction of Th2 responses. Int Immunopharmacol. 2004;4:615-626

[134] Blumberg H, Conklin D, Xu WF, et al. Interleukin 20: discovery, receptor identification, and role in epidermal function. Cell. 2001;104:9-19.

[135] Köks S, Kingo K, Rätsep R, Karelson M, Silm H, Vasar E. Combined haplotype analysis of the interleukin-19 and -20 genes: relationship to plaque-type psoriasis. Genes Immun. 2004:5:662-667.

[136] Dumoutier L, Leemans C, Lejeune D, Kotenko SV, Renauld JC. STAT activation by IL-19, IL-20 and mda-7 through IL20 receptor complexes of two types. $J$ Immunol. 2001;167:3545-3549.

[137] Wang M, Tan Z, Zhang R, Kotenko SV, Liang P. Interleukin 24 (MDA-7/MOB-5) signals through two heterodimeric receptors, IL-22R1/IL-20R2 and IL-20R1/IL-20R2. J Biol Chem. 2001;277:7341-7347.

[138] Parrish-Novak J, Xu W, Brender T, et al. Interleukins 19, 20, and 24 signal through two distinct receptor complexes. Differences in receptor-ligand interactions mediate unique biological functions. J Biol Chem. 2002;277:47517-47523.

[139] Levings MK, Sangregorio R, Sartirana C, et al. Human $\mathrm{CD} 25+\mathrm{CD} 4+\mathrm{T}$ suppressor cell clones produce transforming growth factor beta, but not interleukin 10, and are distinct from type 1 T regulatory cells. $J$ Exp Med. 2002;196:13351346

[140] Rich BE, Kupper TS. Cytokines: IL-20 - a new effector in skin inflammation. Curr Biol. 2001;11:R531-R534.

[141] Otkjaer K, Kragballe K, Funding AT, et all. The dynamics of gene expression of interleukin-19 and interleukin-20 and their receptors in psoriasis. Br J Dermatol. 2005;153: 911-918

[142] Kingo K, Köks S, Nikopensius T, Silm H, Vasar E . Polymorphisms in the interleukin-20 gene: relationships to plaque-type psoriasis. Genes Immun. 2004;5:117-121.

[143] Oppmann B, Lesley R, Blom B, et al. Novel p19 protein engages IL-12p40 to form a cytokine, IL-23, with biological activities similar as well as distinct from IL-12. Immunity. 2000;13:715-725

[144] Blauvelt A. Full court press on psoriasis. J Invest Dermatol. 2004; $123: 7-8$
[145] Parham C, Chirica M, Timans J, et al. A receptor for the heterodimeric cytokine IL-23 is composed of IL-12Rbetal and a novel cytokine receptor subunit, IL-23R. J Immunol. 2002;168:5699-5708.

[146] Wiekowski MT, Leach MW, Evans EW, et al. Ubiquitous transgenic expression of the IL-23 subunit p19 induces multiorgan inflammation, runting, infertility, and premature death. J Immunol. 2001;166:7563-7570.

[147] Cua DJ, Sherlock J, Chen Y, et al. Interleukin-23 rather than interleukin-12 is the critical cytokine for autoimmune inflammation of the brain. Nature. 2003;421:744-748.

[148] Bastos KRB, Marinho CRF, Barboza R, Russo M, Álvarez JM, D'Império Lima MR. What kind of message does IL$12 / \mathrm{IL}-23$ bring to macrophages and dendritic cells? Microbes Infect. 2004;6:630-636.

[149] Goetz FW, Planas JV, MacKenzie S. Tumor necrosis factor. Dev Comp Immunol. 2004;28:487-495.

[150] Schottelius AJG, Moldawer LL, Dinarello CA, Asadullah K, Sterry W, Edwards III CK. Biology of tumor necrosis factor$\alpha$ - implications for psoriasis. Exp Dermatol. 2004;13:193222.

[151] Vandenabeele P, Declercq W, Beyaert R, Fiers W. Two tumour necrosis factor receptors: structure and fuction. Trends Cell Biol. 1995;5:392-399.

[152] Aderka D. The potential biological and clinical significance of the soluble tumor necrosis factor receptors. Cytokine Growth Factor Rev. 1996;7:231-240.

[153] Makhatadze NJ. Tumor Necrosis Factor Locus: Genetic Organisation and Biological Implications. Human Immunol. 1998;59:571-579.

[154] Ware CF. The TNF superfamily. Cytokine Growth Factor Rev. 2003;14:181-184

[155] Numerof RP, Asadullach K. Cytokine and Anti-Cytokine Therapies for Psoriasis and Atopic Dermatitis. Biodrugs. 2006;20:93-103.

[156] Billiau A, Vandenbroeck K. IFN $\gamma$. In: Cytokine reference. T.1. Ed.J.J. Oppenheim et al., Academic Press San Diego. 641-688, 2000

[157] Mühl H, Pfeilschifter J. Anti-inflammatory properties of pro-inflammatory interferon-gamma. International Immunopharmacology. 2003;3:1247-1255 .

[158] Menter A. Recent Advances in Psoriasis Therapy and the Work of the Inter national Psoriasis Council. In: Business Briefing: US Dermatology Review 2006: 23-27.

[159] Gibbs A, Markham T, Walsh C, Bresnihan B, Veale D, FitzGerald O. Anakinra (Kineret) in psoriasis and psoriatic arthritis: a single-center, open-label, pilot study. Arthritis Res Ther. 2005;7;suppl. 1:P68.

[160] Singri P, West DP, Gordon KB. Biologic therapy for psoriasis: The new therapeutic frontier. Arch Dermatol. 2002;138: 657-663.

Submitted:11 August, 2007 Accepted after reviews: 10 October, 2007 